\title{
Produção e composição bromatológica de forrageiras em sistema de integração lavoura-pecuária em diferentes épocas de semeadura
}

\author{
Cristiano Magalhães Pariz ${ }^{(1)}$, Mariana Vieira Azenha ${ }^{(2)}$, Marcelo Andreotti(3), Fabio Cruz de Mello Araújo ${ }^{(4)}$, \\ Nelson de Araújo Ulian ${ }^{(1)}$ e Antonio Fernando Bergamaschine ${ }^{(5)}$
}

\begin{abstract}
(1)Universidade Estadual Paulista (Unesp), Faculdade de Medicina Veterinária e Zootecnia, Departamento de Melhoramento e Nutrição Animal, Caixa Postal 560, CEP 18618-000 Botucatu, SP. E-mail: cmpzoo@gmail.com, nelsinho_ulian@yahoo.com.br (2)Unesp, Faculdade de Ciências Agrárias e Veterinárias, Departamento de Zootecnia, CEP 14884-900 Jaboticabal, SP. E-mail: m240185@hotmail.com ${ }^{(3)}$ Unesp, Faculdade de Engenharia (FE), Departamento de Fitossanidade, Engenharia Rural e Solos, Caixa Postal 31, CEP 15385-000 Ilha Solteira, SP. E-mail: dreotti@agr.feis.unesp.br ${ }^{(4)}$ Central Brasileira de Comunicação, Rua Morás, no 65, CEP 05434-020 São Paulo, SP. E-mail: fabiomello.zootec@gmail.com ${ }^{(5)}$ Unesp, FE, Departamento de Biologia e Zootecnia. E-mail: berga@bio.feis.unesp.br
\end{abstract}

Resumo - O objetivo deste trabalho foi avaliar a produção de matéria seca e a composição bromatológica de forrageiras em sistema de integração lavoura-pecuária, em diferentes datas de semeadura. Foi usado delineamento experimental de blocos ao acaso, em esquema fatorial $4 \times 3$, com quatro forrageiras - braquiária, Urochloa brizantha; capim-moa, Setaria italica; milheto, Pennisetum glaucum; e sorgo forrageiro, Sorghum bicolor - semeadas em três datas nas estações inverno/primavera e verão/outono, em sucessão à soja. O milheto e o sorgo forrageiro produziram maior quantidade de matéria seca em todas as datas de semeadura, nas duas estações de cultivo e, ao contrário da braquiária e do capim-moa, não diminuíram o teor de nutrientes digestíveis totais no inverno/primavera. Os teores de proteína bruta reduziram com o avanço das datas de semeadura no inverno/primavera e aumentaram no verão/outono, exceto para braquiária e milheto. $\mathrm{O}$ sorgo apresentou os menores teores de fibras em detergente neutro nas segunda e terceira datas de semeadura no inverno/primavera, e na primeira data de semeadura no verão/outono. Nas segunda e terceiras datas do inverno/primavera, o sorgo apresentou menor teor de fibras em detergente ácido. Quanto aos constituintes da parede celular, apenas os teores de hemicelulose não se alteram nas forrageiras em virtude das datas de semeadura, em ambas as estações.

Termos para indexação: Pennisetum glaucum, Setaria italica, Sorghum bicolor, Urochloa brizantha, sistema plantio direto.

\section{Yield and chemical composition of forage in crop-livestock integration in different sowing time}

\begin{abstract}
The objective of this work was to evaluate the dry matter yield and chemical composition of forage in crop-livestock integration, according to different sowing dates. A randomized experimental block design in a $4 \times 3$ factorial scheme was used, with four forage plants (palisadegrass, Urochloa brizantha; fox millet, Setaria italica; pearl millet, Pennisetum glaucum; and sorghum, Sorghum bicolor) sowed on three dates, in two season (winter/spring and summer/autumn), in succession to soybean. The pearl millet and sorghum produced the highest amount of dry matter in all sowing dates, at both growing seasons and, contrary to palisadegrass and fox millet, it did not reduce the amount of total digestible nutrients. Crude protein levels decreased with the advancement of sowing dates in winter/spring and increased in summer/autumn, except for palisadegrass and pearl millet. Sorghum showed the lowest concentrations of neutral detergent fiber in the second and third sowing dates in winter/spring, and in the first sowing date in summer/autumn. In the second and third sowing dates in winter/spring, sorghum showed the lowest content of acid detergent fiber. In relation to the cell wall components, only the hemicellulose contents did not change in the forages due to sowing dates, at both seasons.
\end{abstract}

Index terms: Pennisetum glaucum, Setaria italica, Sorghum bicolor, Urochloa brizantha, no-tillage system.

\section{Introdução}

A recuperação de áreas degradadas, a redução dos custos de produção e o uso da área agrícola durante todo o ano têm sido viabilizados pela integração lavoura-pecuária (ILP) em sistema plantio direto (SPD), com resultados socioeconômicos e ambientais positivos (Franzluebbers, 2007; Tracy \& Zhang, 2008; Macedo, 2009).

Pesq. agropec. bras., Brasília, v.46, n.10, p.1392-1400, out. 2011 
A ILP apresenta maior sustentabilidade do que os modernos sistemas de monocultura, que dependem da utilização de grandes quantidades de fertilizantes e inseticidas (Katsvairo et al., 2006). De acordo com Balbinot Júnior et al. (2009), este sistema pressupõe a rotação de culturas em SPD, o uso de genótipos de animais e vegetais melhorados, e o manejo correto da pastagem.

A maior parte das áreas utilizadas para produção de grãos no Cerrado brasileiro permanece em pousio de sete a oito meses, com apenas uma safra por ano agrícola, em virtude das condições climáticas desfavoráveis no início do outono, sobretudo a deficiência hídrica (Aidar et al., 2003). Dessa forma, a semeadura de forrageiras em fevereiro/março, em sucessão à cultura de verão, é uma boa opção. Dependendo do planejamento do produtor, a semeadura na primavera pode fornecer forragem de qualidade aos animais e palhada para a continuidade do SPD no verão (Macedo, 2009).

A maioria dos estudos com ILP se atêm apenas à avaliação da produção de grãos. No entanto, fatores como espécie, fertilidade do solo, maturidade, colheita, processamento, manejo dos animais, armazenamento e condições climáticas (água, temperatura e fotoperíodo) podem afetar a produção de matéria seca, a composição bromatológica e, consequentemente, o teor de energia ou nutrientes digestíveis totais (NDT) da forragem, principalmente em função de alguns componentes da parede celular, como a celulose, a hemicelulose e a lignina (Leonel et al., 2009).

No Cerrado, a sucessão de culturas em ILP ocorre geralmente com a semeadura da cultura granífera em outubro/novembro, com colheita em fevereiro/março. Como o período chuvoso se prolonga até abril/maio, é oportuno utilizar as áreas agrícolas para produção de forrageiras anuais, entre as quais destacam-se o milheto, o sorgo forrageiro e as braquiárias (Aidar et al., 2003). Embora estas espécies forrageiras apresentem amplo período de semeadura (setembro a março), a produção torna-se bastante variável em virtude da época de semeadura. Semeaduras mais tardias devem ser mais bem avaliadas, pois a colheita da forragem em meados de dezembro ou início de janeiro e meados de maio ou início de junho podem alterar o planejamento do produtor.

O objetivo deste trabalho foi avaliar a produção de matéria seca e a composição bromatológica de forrageiras, em sistema de integração lavoura-pecuária, e em diferentes épocas de semeadura.

\section{Material e Métodos}

O experimento foi conduzido no ano agrícola 2006/2007, na Fazenda de Ensino, Pesquisa e Extensão da Faculdade de Engenharia da Universidade Estadual Paulista, Campus de Ilha Solteira, área de produção vegetal, localizada no Município de Selvíria, MS $\left(20^{\circ} 20^{\prime} 05^{\prime \prime} \mathrm{S}\right.$ e $51^{\circ} 22^{\prime} 02^{\prime \prime} \mathrm{W}$, a $335 \mathrm{~m}$ de altitude). O clima, conforme classificação de Köppen, é tropical úmido com estação chuvosa no verão e seca no inverno, do tipo fundamental Aw, e a precipitação média anual é de $1.370 \mathrm{~mm}$. Os dados meteorológicos coletados estão ilustrados na Figura 1.

O solo da área experimental foi classificado como Latossolo Vermelho distroférrico, textura argilosa (Santos et al., 2006). Os atributos físicos e químicos iniciais na camada de 0 a $0,20 \mathrm{~m}$ do solo da área experimental indicaram: densidade do solo de $1,25 \mathrm{~kg} \mathrm{dm}^{-3} ; 0,163,0,314$ e $0,477 \mathrm{~m}^{3} \mathrm{~m}^{-3} \mathrm{de}$ macro, micro e porosidade total, respectivamente; $\mathrm{pH}$ em $\mathrm{CaCl}_{2}$ de 5,2; $26 \mathrm{~g} \mathrm{dm}^{-3}$ de $\mathrm{MO} ; 33 \mathrm{mmol}_{\mathrm{c}} \mathrm{dm}^{-3}$ de $\mathrm{H}+\mathrm{Al} ; 24 \mathrm{mg} \mathrm{dm}^{-3}$ de $\mathrm{P}$ (resina); 3,2, 24 e $13 \mathrm{mmol}_{\mathrm{c}} \mathrm{dm}^{-3} \mathrm{de} \mathrm{K}^{+}, \mathrm{Ca}^{2+} \mathrm{e} \mathrm{Mg}^{2+}$, respectivamente; e $55 \%$ de V. A área experimental apresentava histórico de três anos em SPD, com rotação entre as culturas do feijão, milho e soja. No último ano antes da instalação do experimento, a cultura utilizada foi a da soja. Quando necessário, a área foi irrigada por aspersão (pivô central), em razão de deficits hídricos durante o período experimental.

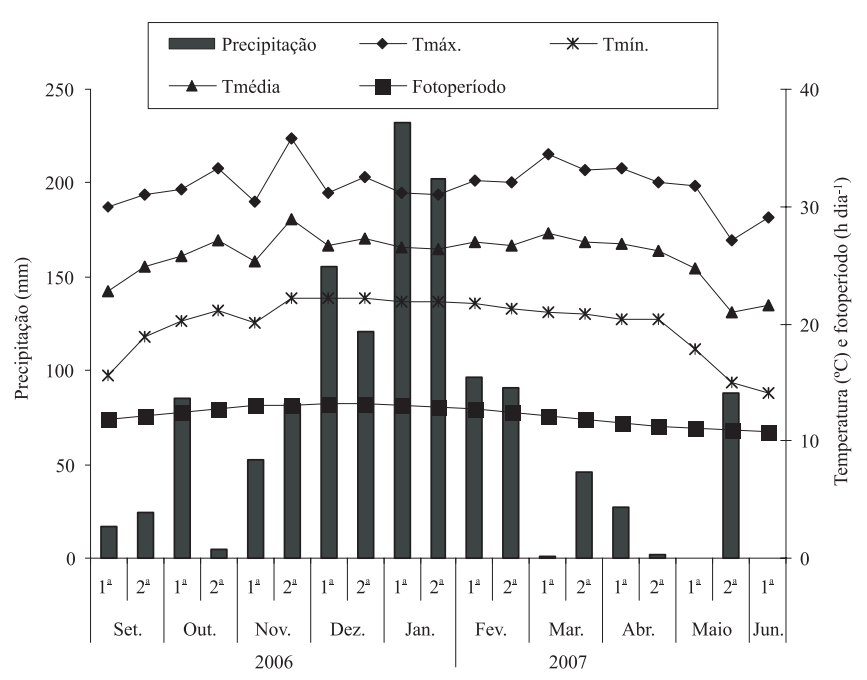

Figura 1. Precipitação pluvial, fotoperíodo e médias de temperatura máxima, mínima e média durante a condução do experimento. 
A semeadura foi realizada em duas estações do ano (inverno/primavera e verão/outono), o que constitui dois experimentos. Em cada estação foi utilizado o delineamento experimental de blocos ao acaso, em esquema fatorial $4 \times 3$, com quatro repetições. Os tratamentos constituíram-se de quatro espécies forrageiras: braquiária brizanta, Urochloa brizantha cv. Marandu (syn. Brachiaria brizantha cv. Marandu); sorgo forrageiro AG 2501C [Sorghum bicolor (Linnaeus) Moench], milheto-pérola cv. BN 2 [Pennisetum glaucum (L.) R. BR.] e capim-moa (Setaria italica L.), em três datas de semeadura, em cada estação (inverno/primavera e verão/outono). $\mathrm{Na}$ estação inverno/primavera, a semeadura da braquiária, do sorgo forrageiro e do milheto ocorreu em 14/9/2006, e a do capim-moa em 11/10/2006, na primeira data. Nas segunda e terceira datas, as semeaduras foram realizadas respectivamente em 28/9/2006 e 11/10/2006, para braquiária, sorgo forrageiro e milheto, e em 26/10/2006 e 9/11/2006, para o capim-moa. A razão para a variação entre as datas de semeadura do capim-moa e das demais forrageiras deveu-se ao ciclo mais curto (45 a 60 dias) da primeira. Dessa forma, para que se obtivessem idades fenológicas semelhantes entre as forrageiras no momento da colheita, foi necessário diferenciar as datas de semeadura. No verão/outono, a semeadura das quatro forrageiras ocorreu em 21/2/2007, 14/3/2007 e 28/3/2007 (primeira, segunda e terceira datas, respectivamente), e não houve variação de dias entre a semeadura do capim-moa e as outras forrageiras, por terem ciclos semelhantes nesta estação.

A área de cada parcela foi $25 \mathrm{~m}^{2}$, e as forrageiras foram semeadas com espaçamento entre linhas de $0,17 \mathrm{~m}$ e 500 pontos de valor cultural (VC) por hectare para a braquiária; $0,45 \mathrm{~m}$ e 20 sementes por metro para o sorgo forrageiro; $0,17 \mathrm{~m}$ e $20 \mathrm{~kg} \mathrm{ha}^{-1}$ de sementes para o milheto; e $0,17 \mathrm{~m}$ e 200 sementes por metro para o capim-moa. Não foi realizada adubação mineral.

Em 06/9/2006 e 14/2/2007, inverno/primavera e verão/outono, respectivamente, a área experimental foi dessecada com os herbicidas glyphosate, $1,44 \mathrm{~kg} \mathrm{ha}^{-1} \mathrm{de}$ i.a. e 2,4-D amina, na dose de $670 \mathrm{~g} \mathrm{ha}^{-1}$ de i.a.

A colheita foi realizada em 3/12/2006, 17/12/2006 e 3/1/2007, para a semeadura no inverno/primavera, e em 2/5/2007, 17/5/2007 e 1/6/2007, para a semeadura no verão/outono. Estas datas são referentes à primeira, segunda e terceira datas de semeadura em cada estação, respectivamente (estádio inicial de enchimento de grãos do sorgo forrageiro, do milheto e do capim-moa, e estádio vegetativo da braquiária), o que correspondeu a 75 dias após a emergência (DAE) da braquiária, do sorgo forrageiro e do milheto, e 50 DAE do capim-moa no inverno/primavera, e $56 \mathrm{DAE}$ das quatro forrageiras no verão/outono. Colheu-se manualmente uma área de $1 \mathrm{~m}^{2}$ (quadrado de metal), na altura de corte de $0,30 \mathrm{~m}$ em relação à superfície do solo. Essa altura foi escolhida para possibilitar a colheita de maior quantidade de folhas na braquiária e a formação de resíduos para a formação de palhada em todas as espécies forrageiras. Após a colheita, o material foi pesado e colocado em estufa de circulação forçada de ar, a $65^{\circ} \mathrm{C}$, até massa constante, para determinação da produção de matéria seca (PMS). Depois de moídas em moinho tipo Willey, as amostras foram submetidas às análises bromatológicas, e foram estimados os teores de nutrientes digestíveis totais (NDT), conforme Cappelle et al. (2001), e determinados os teores de proteína bruta (PB), fibra em detergente neutro (FDN), fibra em detergente ácido (FDA), hemicelulose, celulose e lignina, de acordo com metodologia descrita por Silva \& Queiroz (2002).

Os dados de cada variável, em cada estação de cultivo, foram submetidos à análise de variância, com teste $\mathrm{F}$ a $5 \%$ de probabilidade (Tabela 1) e, posteriormente, foi realizada a comparação de médias pelo teste de Tukey, também a 5\% de probabilidade. Foi utilizado o programa Sisvar (Ferreira, 1999) para as análises estatísticas.

\section{Resultados e Discussão}

No inverno/primavera, apenas a braquiária apresentou queda significativa na PMS, em razão da semeadura na primeira data (Tabela 2). Este resultado pode ser explicado pela sensibilidade de $U$. brizantha a baixas temperaturas. Conforme Müller et al. (2002), no inverno, o crescimento das gramíneas forrageiras tropicais é influenciado por temperaturas baixas e, no final do inverno, as mínimas estiveram entre $15 \mathrm{e}$ $20^{\circ} \mathrm{C}$ (Figura 1). Com o aumento da temperatura e do fotoperíodo no início da primavera, as demais datas de semeadura proporcionaram maior PMS dessa espécie forrageira.

$\mathrm{Na}$ primeira data, o milheto e o sorgo forrageiro apresentaram maior PMS; nas demais datas, a PMS 
da braquiária igualou-se à destas duas espécies forrageiras. Em todas as datas de semeadura, a PMS do capim-moa foi menor em comparação às outras espécies forrageiras, o que demonstra menor capacidade produtiva, independentemente da data de semeadura no inverno/primavera. A PMS, nas três datas de semeadura, foi superior aos $6.500 \mathrm{~kg} \mathrm{ha}^{-1}$ obtidos por Andreotti et al. (2008) no mesmo período de avaliação, em um Latossolo Vermelho em SPD, em Palotina, PR.

No verão/outono, apenas o sorgo forrageiro apresentou queda na PMS em razão da semeadura na terceira data (Tabela 2). O milheto e o sorgo forrageiro apresentaram as maiores PMS entre as forrageiras, nas duas primeiras datas de semeadura, enquanto, na terceira data, o milheto destacou-se com maior PMS. A diminuição da PMS do sorgo forrageiro na terceira data pode ser explicada pelo decréscimo do fotoperíodo no início do outono, aliado a períodos de ausência de chuva (Figura 1), o que indica que esta espécie forrageira é mais sensível a esses fatores. Resultados semelhantes foram verificados por Silva et al. (2005) com a mesma cultivar de sorgo forrageiro, a AG 2501C, em Coimbra, $\mathrm{MG}$, nas semeaduras realizadas em outubro, fevereiro e março, o que demonstra que, independentemente do local, a diminuição do fotoperíodo é determinante da PMS desta forrageira. A PMS do capim-moa foi semelhante à da braquiária no verão/outono, mas não no inverno/primavera (Tabela 2). A diferença entre DAE, para atingir o mesmo estádio fenológico (estádio inicial de enchimento de grãos do sorgo forrageiro e do milheto e estádio vegetativo da braquiária) nas estações de crescimento - 75 DAE no inverno/primavera e 56 DAE no verão/outono - pode ter influenciado a PMS (Andreotti et al., 2008). O capim-moa, ao ser semeado no inverno/primavera e no verão/outono (50 e 56 DAE, respectivamente), apresenta ciclos semelhantes, o que indica que, diferentemente das outras forrageiras, em especial da $U$. brizantha, ele é uma espécie forrageira menos susceptível aos efeitos climáticos de temperatura e fotoperíodo, que influenciam o número de dias para a diferenciação floral (Geraldo et al., 2002).

Oliveira et al. (2000) sugerem que se faça um planejamento na ILP para que o milheto seja utilizado para corte ou pastejo dos 60 aos 80 DAE. Os resultados deste trabalho corroboram os dos autores, uma vez que o momento do corte foi atingido aos 75 e 56 DAE no inverno/primavera e no verão/outono, respectivamente. Segundo Norman et al. (1995), a cultivar de milheto BN 2 pode ser considerada de dias curtos, porque a espécie tem iniciação floral induzida por fotoperíodo menor do que o seu fotoperíodo crítico e por baixa temperatura ambiente, o que explica a diferença entre DAE para o corte da forrageira nas estações avaliadas.

Quanto aos teores de nutrientes, a braquiária e o capim-moa, semeados no inverno/primavera, apresentaram diminuição dos teores de NDT da primeira para a terceira datas de semeadura, enquanto no verão/outono, a primeira data proporcionou menores valores do que as demais (Tabela 3 ). O milheto e o sorgo forrageiro não apresentaram alterações nos teores de NDT de acordo com as datas de semeadura, nas duas estações. O sorgo forrageiro, em todas as datas, e o capim-moa, na primeira da estação inverno/primavera, apresentaram os maiores teores de NDT entre as forrageiras. No verão/outono, o teor de NDT foi maior no sorgo forrageiro apenas na primeira data de semeadura; nas demais, foi semelhante a todas as forrageiras. De acordo com Van Soest (1994), o teor de NDT de forrageiras é de aproximadamente $55 \%$.

Tabela 1. Análise de variância da produção de matéria seca (PMS), e dos teores de nutrientes digestíveis totais (NDT), proteína bruta (PB), fibra em detergente neutro (FDN) e ácido (FDA), celulose (CEL), hemicelulose (HEM) e lignina (LIG), de acordo com a forrageira e com a época de semeadura.

\begin{tabular}{|c|c|c|c|c|c|c|c|c|}
\hline Fator de variação & PMS & NDT & $\mathrm{PB}$ & FDN & FDA & CEL & HEM & LIG \\
\hline & \multicolumn{8}{|c|}{ Inverno/Primavera } \\
\hline Forrageira (A) & $34,68 * *$ & $146,65 * *$ & $92,80 * *$ & $146,65 * *$ & $61,68 * *$ & $146,71 * *$ & $4,98 * *$ & $19,02 * *$ \\
\hline Data (B) & $2,04^{\mathrm{ns}}$ & $20,77 * *$ & $8,82 * *$ & $20,77 * *$ & $21,92 * *$ & $31,77 * *$ & $4,30^{*}$ & $19,00 * *$ \\
\hline \multirow[t]{2}{*}{$\mathrm{AxB}$} & $4,90 * *$ & $7,12 * *$ & $2,62 *$ & $7,12 * *$ & $2,86^{*}$ & $3,07 *$ & $1,93^{\mathrm{ns}}$ & $4,34 * *$ \\
\hline & \multicolumn{8}{|c|}{ Verão/Outono } \\
\hline Forrageira (A) & $43,84 * *$ & $10,40 * *$ & $10,07 * *$ & $10,40^{* *}$ & $0,73^{\text {ns }}$ & $3,80 *$ & $31,28 * *$ & $7,89 * *$ \\
\hline Data (B) & $12,54 * *$ & $13,26^{* *}$ & $24,67 * *$ & $13,36^{* *}$ & $19,17 * *$ & $25,61 * *$ & $6,77 * *$ & $10,03 * *$ \\
\hline $\mathrm{AxB}$ & $2,83 *$ & $3,14 *$ & $2,66^{*}$ & $3,14 *$ & $3,16^{*}$ & $4,53 * *$ & $3,89 * *$ & $2,83^{*}$ \\
\hline
\end{tabular}

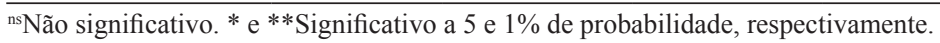


No geral, os resultados deste trabalho ficaram próximos a este teor, assim como dos obtidos por Benett et al. (2008) com $U$. brizantha cv. Marandu, em diferentes épocas de corte, em condições ambientais e de solo semelhantes.

Entre as datas de semeadura no inverno/primavera, a braquiária não apresentou diferença no teor de PB. $\mathrm{O}$ teor no capim-moa foi maior nas duas primeiras datas, e, nas outras forrageiras, foi maior na primeira em comparação à terceira (Tabela 3 ). Andreotti et al.

Tabela 2. Produção de matéria seca $\left(\mathrm{kg} \mathrm{ha}^{-1}\right)$ das forragens avaliadas, em três datas de semeadura, e duas estações ${ }^{(1)}$.

\begin{tabular}{|c|c|c|c|c|}
\hline $\begin{array}{l}\text { Data de } \\
\text { semeadura }^{(2)}\end{array}$ & $\begin{array}{l}\text { Urochloa } \\
\text { brizantha }\end{array}$ & $\begin{array}{c}\text { Setaria } \\
\text { italica }\end{array}$ & $\begin{array}{c}\text { Pennisetum } \\
\text { glaucum }\end{array}$ & $\begin{array}{c}\text { Sorghum } \\
\text { bicolor }\end{array}$ \\
\hline & \multicolumn{4}{|c|}{ Inverno/Primavera } \\
\hline $14 / 9 / 2006$ & $13.838 \mathrm{bB}$ & $9.868 \mathrm{cA}$ & $25.206 \mathrm{aA}$ & $21.511 \mathrm{aA}$ \\
\hline $28 / 9 / 2006$ & $19.147 \mathrm{aA}$ & $9.059 \mathrm{bA}$ & $20.191 \mathrm{aA}$ & $23.522 \mathrm{aA}$ \\
\hline $11 / 10 / 2006$ & $20.000 \mathrm{aA}$ & $7.618 \mathrm{bA}$ & $23.824 \mathrm{aA}$ & $23.778 \mathrm{aA}$ \\
\hline Média & 17.662 & 8.848 & 23.074 & 22.937 \\
\hline \multirow[t]{2}{*}{ CV $(\%)$} & \multicolumn{4}{|c|}{21,7} \\
\hline & \multicolumn{4}{|c|}{ Verão/Outono } \\
\hline $21 / 2 / 2007$ & $5.400 \mathrm{bA}$ & $6.618 \mathrm{bA}$ & $15.735 \mathrm{aA}$ & $16.111 \mathrm{aA}$ \\
\hline $14 / 3 / 2007$ & $4.480 \mathrm{bA}$ & $6.647 \mathrm{bA}$ & $14.485 \mathrm{aA}$ & $13.556 \mathrm{aA}$ \\
\hline $28 / 3 / 2007$ & $3.162 \mathrm{bA}$ & $6.588 \mathrm{bA}$ & $12.794 \mathrm{aA}$ & $6.444 \mathrm{bB}$ \\
\hline Média & 4.587 & 6.618 & 14.338 & 12.037 \\
\hline $\mathrm{CV}(\%)$ & \multicolumn{4}{|c|}{25,4} \\
\hline
\end{tabular}

${ }^{(1)}$ Médias seguidas de letras iguais, minúsculas nas linhas e maiúsculas nas colunas, não diferem entre si pelo teste de Tukey, a 5\% de probabilidade. ${ }^{(2)}$ No inverno/primavera, para S. italica, as datas foram: 11/10/2006, $26 / 10 / 2006$ e $09 / 11 / 2006$, respectivamente. No verão/outono, as datas foram as mesmas, para todas as forrageiras avaliadas.
(2008) verificaram valores de aproximadamente $13 \%$ de PB no capim-moa, teores maiores que os verificados neste trabalho, provavelmente porque a avaliação foi realizada no estádio de floração. No verão/outono, os teores de PB do milheto não apresentaram diferenças entre as datas de semeadura, enquanto a braquiária apresentou elevação dos teores da primeira para a terceira data, e as outras forrageiras apresentaram maior teor na terceira data.

Em ambas as estações do ano, as elevações nos teores de PB (Tabela 3) foram verificadas nas datas com menores temperaturas e fotoperíodo (Figura 1). De acordo com Carvalho et al. (1997), em condições de luminosidade reduzida, as plantas forrageiras mudam sua estrutura e concentração de nutrientes. A planta pode alterar seu metabolismo para o acúmulo de nitrogênio (N), como verificado por Soares et al. (2009). Os resultados deste trabalho concordam com Wilson (1996), que afirma que esse fenômeno está relacionado ao maior teor de umidade, associado à temperatura do solo em condições de temperaturas mais amenas, o que favorece as taxas de mineralização e a ciclagem de N. As concentrações deste nutriente são maiores em plantas em condições de menor luminosidade e temperatura (Kephart \& Buxton, 1993).

Em todas as datas de semeadura no inverno/ primavera, o capim-moa apresentou maior teor de PB (Tabela 3). Em geral, com o avanço da idade da planta, há decréscimo no teor de PB (Van Soest, 1994). Os menores teores foram verificados no sorgo

Tabela 3. Teores de nutrientes digestíveis totais (NDT, \%) e proteína bruta (PB,\%) das forragens avaliadas, em três datas de semeadura, em duas estações ${ }^{(1)}$.

\begin{tabular}{|c|c|c|c|c|c|c|c|c|}
\hline \multirow[t]{2}{*}{ Data de semeadura ${ }^{(2)}$} & \multicolumn{2}{|c|}{ Urochloa brizantha } & \multicolumn{2}{|c|}{ Setaria inca } & \multicolumn{2}{|c|}{ Pennisetum glaucum } & \multicolumn{2}{|c|}{ Sorghum bicolor } \\
\hline & NDT & $\mathrm{PB}$ & NDT & PB & NDT & PB & NDT & PB \\
\hline & \multicolumn{8}{|c|}{ Inverno/Primavera } \\
\hline $14 / 9 / 2006$ & $53,5 \mathrm{bA}$ & $6,2 \mathrm{bA}$ & $56,0 \mathrm{aA}$ & $9,4 \mathrm{aA}$ & $52,6 \mathrm{bA}$ & $6,8 \mathrm{bA}$ & $55,9 \mathrm{aA}$ & $5,0 \mathrm{bA}$ \\
\hline $28 / 9 / 2006$ & $52,0 \mathrm{cB}$ & $5,7 \mathrm{bA}$ & $54,7 \mathrm{bB}$ & $9,7 \mathrm{aA}$ & $52,7 \mathrm{bA}$ & $6,1 \mathrm{bAB}$ & $56,8 \mathrm{aA}$ & $3,8 \mathrm{cAB}$ \\
\hline $11 / 10 / 2006$ & $51,0 \mathrm{cC}$ & $5,7 \mathrm{bA}$ & $53,2 \mathrm{bC}$ & $8,0 \mathrm{aB}$ & $52,2 \mathrm{bA}$ & $5,5 \mathrm{bB}$ & $56,3 \mathrm{aA}$ & $3,4 \mathrm{cB}$ \\
\hline Média & 52,2 & 5,9 & 54,6 & 9,0 & 52,9 & 6,1 & 56,3 & 4,1 \\
\hline \multirow[t]{2}{*}{$\mathrm{CV}(\%)$} & 11,1 & 11,7 & 11,1 & 11,7 & 11,1 & 11,7 & 11,1 & 11,7 \\
\hline & \multicolumn{8}{|c|}{ Verão/Outono } \\
\hline $21 / 2 / 2007$ & $54,9 \mathrm{bB}$ & $8,3 \mathrm{abC}$ & $54,2 \mathrm{bB}$ & $9,2 \mathrm{aAB}$ & $56,1 \mathrm{abA}$ & $7,8 \mathrm{abA}$ & $58,0 \mathrm{aA}$ & $6,1 \mathrm{bB}$ \\
\hline $14 / 3 / 2007$ & $57,7 \mathrm{aA}$ & $11,9 \mathrm{aB}$ & $56,3 \mathrm{aA}$ & $8,7 \mathrm{abB}$ & $57,2 \mathrm{aA}$ & $9,4 \mathrm{abA}$ & $57,9 \mathrm{aA}$ & $7,2 \mathrm{bB}$ \\
\hline $28 / 3 / 2007$ & $57,6 \mathrm{aA}$ & $15,3 \mathrm{aA}$ & $56,8 \mathrm{aA}$ & $12,4 \mathrm{aA}$ & $57,8 \mathrm{aA}$ & $8,6 \mathrm{bA}$ & $57,8 \mathrm{aA}$ & $12,0 \mathrm{abA}$ \\
\hline Média & 56,7 & 11,8 & 55,8 & 10,1 & 57,0 & 8,6 & 57,9 & 8,1 \\
\hline $\mathrm{CV}(\%)$ & 11,8 & 20,8 & 11,8 & 20,8 & 11,8 & 20,8 & 11,8 & 20,8 \\
\hline
\end{tabular}

${ }^{(1)}$ Médias seguidas de letras iguais, minúsculas nas linhas e maiúsculas nas colunas, não diferem entre si pelo teste de Tukey, a 5\% de probabilidade. ${ }^{(2)}$ No inverno/primavera, para S. italica, as datas foram: 11/10/2006, 26/10/2006 e 09/11/2006, respectivamente. No verão/outono, as datas foram as mesmas, para todas as forrageiras avaliadas. 
forrageiro, nas segunda e terceira datas de semeadura. No verão/outono, a braquiária apresentou maiores teores de PB do que o sorgo forrageiro na segunda data, e teores semelhantes aos das outras forrageiras nas demais datas.

Em relação aos constituintes da parece celular, na comparação entre datas de semeadura no inverno/primavera, os maiores teores de FDN da braquiária e do capim-moa ocorreram na terceira data, enquanto os do milheto ocorreram nas primeira e segunda datas. Já o sorgo não apresentou diferenças entre as datas de semeadura (Tabela 4). No verão/outono, os maiores teores de FDN da braquiária ocorreram na primeira data, e não se verificaram diferenças entre as datas de semeadura para as outras forrageiras. O sorgo forrageiro apresentou teores menores de FDN na segunda e terceira datas, no inverno/primavera, e na primeira data no verão/outono, em comparação às outras forrageiras. Conforme Van Soest (1994), os teores de FDN da forragem influenciam o consumo pelos ruminantes. Portanto, na estação de inverno/primavera, a melhor opção é o sorgo forrageiro semeado em qualquer data, e, na estação de verão/outono, o sorgo forrageiro semeado na primeira data. Independentemente da data de semeadura, a braquiária no inverno/primavera e o capim-moa no verão/outono são as opções menos viáveis, no que se refere aos teores de FDN.

No inverno/primavera, os teores de FDA no capim-moa e no milheto foram maiores na terceira data de semeadura. Também foram maiores na braquiária no verão/outono e no capim-moa na primeira data de semeadura, mas não se alteraram no milheto $\mathrm{e}$ no sorgo forrageiro (Tabela 4). Na primeira data de semeadura, verificou-se menor teor de FDA no milheto e no sorgo forrageiro, em comparação à braquiária, e menores teores de PB. De acordo com Van Soest (1994), o aumento da parede celular compensa a menor quantidade de constituintes presentes no interior das células, entre eles o $\mathrm{N}$, precursor da $\mathrm{PB}$. De modo inverso, a elevação dos teores de PB reduz os teores de FDA. As menores PMS verificadas no verão/outono também podem explicar os menores teores de FDA nesta estação, já que plantas com crescimento mais lento necessitam de menor quantidade de parede celular composta por FDA, para sua sustentação.

A colheita aos 75 DAE no inverno/primavera pode ter contribuído para os maiores teores de FDA da braquiária em comparação ao capim-moa e ao sorgo forrageiro (Tabela 4). A espécie apresentou ótima emergência e acelerado crescimento inicial, em razão da utilização de sementes de alto VC, da alta densidade de semeadura e das condições climáticas e de solo. A antecipação do corte poderia diminuir os teores de FDA, mas também reduziria a PMS. A altura de corte de $0,30 \mathrm{~m}$ em relação à superfície do solo, para todas as espécies forrageiras, é ideal para colher maior quantidade de folhas, uma vez que alturas inferiores provavelmente elevariam os teores de FDN e FDA em virtude da maior participação de colmos no material amostrado.

Tabela 4. Teores de fibra em detergente neutro (FDN, \%) e ácido (FDA, \%) das forragens avaliadas, em três datas de semeadura, em duas estações ${ }^{(1)}$.

\begin{tabular}{|c|c|c|c|c|c|c|c|c|}
\hline \multirow[t]{2}{*}{ Data de semeadura $^{(2)}$} & \multicolumn{2}{|c|}{ Urochloa brizantha } & \multicolumn{2}{|c|}{ Setaria italica } & \multicolumn{2}{|c|}{ Pennisetum glaucum } & \multicolumn{2}{|c|}{ Sorghum bicolor } \\
\hline & FDN & FDA & FDN & FDA & FDN & FDA & FDN & FDA \\
\hline & \multicolumn{8}{|c|}{ Inverno/Primavera } \\
\hline $14 / 9 / 2006$ & $75,1 \mathrm{aB}$ & $51,9 \mathrm{aA}$ & $66,6 \mathrm{bC}$ & $42,8 \mathrm{bC}$ & $74,7 \mathrm{aA}$ & $49,7 \mathrm{aAB}$ & $66,8 \mathrm{bA}$ & $43,2 \mathrm{bA}$ \\
\hline $28 / 9 / 2006$ & $76,2 \mathrm{aB}$ & $52,3 \mathrm{aA}$ & $69,8 \mathrm{bB}$ & $46,3 \mathrm{bcB}$ & $75,8 \mathrm{aA}$ & $49,2 \mathrm{abB}$ & $64,6 \mathrm{cA}$ & $43,2 \mathrm{cA}$ \\
\hline $11 / 10 / 2006$ & $78,7 \mathrm{aA}$ & $54,7 \mathrm{aA}$ & $73,4 \mathrm{bA}$ & $51,1 \mathrm{bA}$ & $72,0 \mathrm{bB}$ & $52,4 \mathrm{abA}$ & $65,9 \mathrm{cA}$ & $45,2 \mathrm{cA}$ \\
\hline Média & 76,7 & 53,0 & 69,9 & 46,7 & 74,2 & 50,4 & 65,8 & 43,9 \\
\hline \multirow[t]{2}{*}{$\mathrm{CV}(\%)$} & 1,9 & 3,7 & 1,9 & 3,7 & 1,9 & 3,7 & 1,9 & 3,7 \\
\hline & \multicolumn{8}{|c|}{ Verão/Outono } \\
\hline $21 / 2 / 2007$ & $69,4 \mathrm{aA}$ & $42,3 \mathrm{aA}$ & $71,0 \mathrm{aA}$ & $39,4 \mathrm{abA}$ & $66,5 \mathrm{bA}$ & $37,0 \mathrm{bA}$ & $61,7 \mathrm{cA}$ & $36,3 \mathrm{bA}$ \\
\hline $14 / 3 / 2007$ & $62,7 \mathrm{aB}$ & $35,4 \mathrm{aB}$ & $66,9 \mathrm{aA}$ & $36,2 \mathrm{aAB}$ & $63,7 \mathrm{aA}$ & $35,9 \mathrm{aA}$ & $62,2 \mathrm{aA}$ & $36,9 \mathrm{aA}$ \\
\hline $28 / 3 / 2007$ & $60,4 \mathrm{bB}$ & $33,2 \mathrm{aB}$ & $67,1 \mathrm{aA}$ & $34,0 \mathrm{aB}$ & $62,3 \mathrm{bA}$ & $34,7 \mathrm{aA}$ & $62,3 \mathrm{bA}$ & $34,4 \mathrm{aA}$ \\
\hline Média & 64,2 & 37,0 & 68,3 & 36,5 & 64,2 & 35,9 & 62,1 & 35,9 \\
\hline $\mathrm{CV}(\%)$ & 3,9 & 5,9 & 3,9 & 5,9 & 3,9 & 5,9 & 3,9 & 5,9 \\
\hline
\end{tabular}

(1)Médias seguidas de letras iguais, minúsculas nas linhas e maiúsculas nas colunas, não diferem entre si pelo teste de Tukey, a $5 \%$ de probabilidade. ${ }^{(2)}$ No inverno/primavera, para S. italica, as datas foram: 11/10/2006, 26/10/2006 e 09/11/2006, respectivamente. No verão/outono, as datas foram as mesmas, para todas as forrageiras avaliadas. 
Quanto maior o teor de FDA, menor a digestibilidade. O FDN tem correlação negativa com o consumo das forrageiras, ao considerar-se teores de $40 \%$ de FDA e $60 \%$ de FDN como limitantes da digestibilidade e do consumo, respectivamente (Van Soest, 1994). Por causa dos menores teores de FDA, a semeadura do sorgo, na segunda e terceira datas do inverno/ primavera e na primeira data do verão/outono, aumenta o consumo da forragem em decorrência dos menores valores de FDN, em comparação às outras forrageiras. A semeadura do sorgo nas segunda e terceira datas do inverno/primavera melhora a digestibilidade da forragem em razão dos menores teores de FDA, em comparação às outras forrageiras (Tabela 4).

Houve elevação dos teores de celulose no capim-moa, no milheto e no sorgo forrageiro na terceira data de semeadura no inverno/primavera, e diminuição deste teor na braquiária e no capim-moa nas segunda e terceira datas do verão/outono (Tabela 5). No inverno/primavera, a braquiária apresentou maiores teores de celulose que as outras forrageiras, em todas as datas de semeadura. Não houve alterações nos teores de hemicelulose entre as diferentes forrageiras e datas de semeadura no inverno/primavera. No verão/outono, também não houve alteração nas diferentes datas, porém, verificaram-se maiores teores de celulose no capim-moa nas primeira e segunda datas, em comparação ao sorgo forrageiro, e, na terceira data, em comparação ao milheto e ao sorgo forrageiro. Conforme Silva \& Queiroz (2002), a celulose representa a maior parte da FDA, e a hemicelulose, mais digerível que a celulose, integra a FDN. São interessantes maiores teores de hemicelulose e menores de celulose, já que os ruminantes desdobram esses componentes por meio de sua flora bacteriana em ácidos graxos de cadeia curta (AGCC), principalmente acético, propiônico e butírico, que representam a maior fonte de energia quando a alimentação desses animais é a base de forragem. Em relação aos teores de celulose, as melhores opções seriam semear o capim-moa na primeira data, o sorgo forrageiro em qualquer data do inverno/primavera, e a braquiária e o capim-moa nas duas últimas datas do verão/outono.

Os teores de lignina no inverno/primavera foram menores na braquiária e no milheto na primeira data de semeadura. O inverso ocorreu no sorgo forrageiro, com maiores teores na primeira data (Tabela 5). No verão/outono, na primeira data de semeadura, os teores de lignina foram maiores na braquiária e no capim-moa, mas foram reduzidos nas segunda e terceira datas. A importância da lignina na nutrição animal está relacionada ao fato de existirem fortes evidências de que os polissacarídeos da parede celular, tais como celulose, hemicelulose e pectatos, ao serem isolados, apresentam maior degradação por microrganismos do rúmen ou por enzimas (Van Soest, 1994). A degradação é raramente completa, e diminui com o aumento do teor de lignina, além de ser influenciada pela espécie e idade da planta; por isso, menores teores de lignina são desejáveis na forragem (Silva \& Queiroz, 2002). No que se refere aos teores de lignina, a semeadura da braquiária e do milheto na primeira data, do sorgo

Tabela 5. Teores (\%) de celulose (CEL), hemicelulose (HEM) e lignina (LIG) das forragens avaliadas, em três datas de semeadura, em duas estações ${ }^{(1)}$.

\begin{tabular}{|c|c|c|c|c|c|c|c|c|c|c|c|c|}
\hline \multirow{2}{*}{$\begin{array}{l}\text { Data de } \\
\text { semeadura }^{(2)}\end{array}$} & \multicolumn{3}{|c|}{ Urochloa brizantha } & \multicolumn{3}{|c|}{ Setaria italica } & \multicolumn{3}{|c|}{ Pennisetum glaucum } & \multicolumn{3}{|c|}{ Sorghum bicolor } \\
\hline & CEL & HEM & LIG & CEL & HEM & LIG & CEL & HEM & LIG & CEL & HEM & LIG \\
\hline & \multicolumn{12}{|c|}{ Inverno/Primavera } \\
\hline $14 / 9 / 2006$ & $42,8 \mathrm{aA}$ & - & $6,2 \mathrm{bB}$ & $33,5 \mathrm{cC}$ & - & $7,8 \mathrm{aA}$ & $38,8 \mathrm{bB}$ & - & $7,9 \mathrm{aB}$ & $33,6 \mathrm{cB}$ & - & $9,1 \mathrm{aA}$ \\
\hline $28 / 9 / 2006$ & $44,0 \mathrm{aA}$ & - & $7,2 \mathrm{bA}$ & $36,4 \mathrm{cB}$ & - & $7,6 \mathrm{bA}$ & $39,2 \mathrm{bB}$ & - & $9,6 \mathrm{aA}$ & $34,6 \mathrm{cAB}$ & - & $7,3 \mathrm{bB}$ \\
\hline $11 / 10 / 2006$ & $44,2 \mathrm{aA}$ & - & $8,0 \mathrm{abA}$ & $39,3 \mathrm{cA}$ & - & $8,0 \mathrm{abA}$ & $41,5 \mathrm{bA}$ & - & $9,1 \mathrm{aA}$ & $36,4 \mathrm{dA}$ & - & $7,5 \mathrm{bB}$ \\
\hline Média & 43,7 & - & 7,2 & 36,4 & - & 7,8 & 39,8 & - & 8,9 & 34,9 & - & 7,9 \\
\hline \multirow[t]{2}{*}{$\mathrm{CV}(\%)$} & 2,9 & - & 7,1 & 2,9 & - & 7,1 & 2,9 & - & 7,1 & 2,9 & - & 7,1 \\
\hline & \multicolumn{12}{|c|}{ Verão/ Outono } \\
\hline $21 / 2 / 2007$ & $34,6 \mathrm{aA}$ & $27,1 \mathrm{bcA}$ & $5,4 \mathrm{bA}$ & $29,8 \mathrm{bA}$ & $31,6 \mathrm{aA}$ & $6,7 \mathrm{aA}$ & $29,9 \mathrm{bA}$ & $31,6 \mathrm{aA}$ & $4,6 \mathrm{bA}$ & $29,6 \mathrm{bA}$ & $31,6 \mathrm{aA}$ & $4,9 \mathrm{bA}$ \\
\hline $14 / 3 / 2007$ & $28,7 \mathrm{aB}$ & $27,3 \mathrm{abA}$ & $4,0 \mathrm{bB}$ & $27,9 \mathrm{aB}$ & $31,8 \mathrm{aA}$ & $5,2 \mathrm{abB}$ & $28,8 \mathrm{aA}$ & $31,8 \mathrm{aA}$ & 4,4abA & $29,1 \mathrm{aA}$ & $31,8 \mathrm{aA}$ & $5,4 \mathrm{aA}$ \\
\hline $28 / 3 / 2007$ & $25,9 \mathrm{abB}$ & $27,3 \mathrm{abA}$ & $4,1 \mathrm{aB}$ & $25,0 \mathrm{bB}$ & $33,1 \mathrm{aA}$ & $4,9 \mathrm{aB}$ & $28,5 \mathrm{aA}$ & $33,1 \mathrm{aA}$ & $4,0 \mathrm{aA}$ & $27,9 \mathrm{abA}$ & $33,1 \mathrm{aA}$ & $4,3 \mathrm{aA}$ \\
\hline Média & 29,8 & 23,7 & 4,5 & 27,5 & 23,2 & 5,6 & 29,1 & 23,2 & 4,4 & 28,9 & 23,2 & 4,9 \\
\hline $\mathrm{CV}(\%)$ & 5,8 & 4,7 & 14,1 & 5,8 & 4,7 & 14,1 & 5,8 & 4,7 & 14,1 & 5,8 & 4,7 & 14,1 \\
\hline
\end{tabular}

${ }^{(1)}$ Médias seguidas por letras iguais, minúsculas nas linhas e maiúsculas nas colunas, não diferem entre si pelo teste de Tukey, a $5 \%$ de probabilidade. ${ }^{(2)}$ No inverno/primavera, para S. italica, as datas foram: 11/10/2006, 26/10/2006 e 09/11/2006, respectivamente. No verão/outono, as datas foram as mesmas, para todas as forrageiras avaliadas. 
forrageiro nas duas últimas datas do inverno/primavera, e da braquiária e do capim-moa nas duas últimas datas do verão/outono são as melhores opções.

\section{Conclusões}

1. Pennisetum glaucum e Sorghum bicolor não diminuem o teor de nutrientes digestíveis totais em função das datas de semeadura e produzem maior quantidade de matéria seca em todas as datas, nas duas estações de cultivo.

2. Somente $P$. glaucum e Setaria italica não alteram a produção de matéria seca em função das datas de semeadura, nas duas estações de cultivo.

3. Urochloa brizantha e S. italica, com o avanço das datas de semeadura, apresentam diminuição dos nutrientes, no inverno/primavera, e aumento no verão/outono.

4. Em geral, os teores de proteína bruta são reduzidos com o avanço das datas de semeadura, no inverno/primavera, e aumentam no verão/outono, exceto para $U$. brizantha e $P$. glaucum.

5. Os menores teores de fibra em detergente neutro e de fibra em detergente ácido apresentados por S. bicolor, na segunda e na terceira época do inverno/primavera e na primeira época do verão/outono, o caracterizam como forragem de maior potencial de consumo e de alta digestibilidade.

6. Apenas os teores de hemicelulose não se alteram em razão das épocas de semeadura, nas duas estações de cultivo.

\section{Agradecimentos}

À Fundação de Amparo à Pesquisa do Estado de São Paulo, pela bolsa de iniciação científica concedida a Cristiano Magalhães Pariz.

\section{Referências}

AIDAR, H.; RODRIGUES, J.A.S.; KLUTHCOUSKI, J. Uso da integração lavoura-pecuária para produção de forragem na entressafra. In: KLUTHCOUSKI, J.; STONE, L.F.; AIDAR, H. (Ed.). Integração lavoura-pecuária. Santo Antônio de Goiás: Embrapa Arroz e Feijão, 2003. p.225-262.

ANDREOTTI, M.; ARALDI, M.; GUIMARÃES, V.F.; FURLANI JÚNIOR, E.; BUZETTI, S. Produtividade do milho safrinha e modificações químicas de um latossolo em sistema plantio direto em função de espécies de cobertura após calagem superficial. Acta Scientiarum. Agronomy, v.30, p.109-115, 2008.
BALBINOT JUNIOR, A.A.; MORAES, A. de; VEIGA, M. de; PELISSARI, A.; DIECKOW, J. Integração lavoura-pecuária: intensificação de uso de área agrícolas. Ciência Rural, v.39, p.1925-1933, 2009.

BENETT,C.G.S.;BUZETTI,S.;SILVA,K.S.;BERGAMASCHINE, A.F.; FABRICIO, J.A. Produtividade e composição bromatológica do capim-Marandu a fontes e doses de nitrogênio. Ciência e Agrotecnologia, v.32, p.1629-1636, 2008.

CAPPELLE, E.R.; VALADARES FILHO, S. de C.; SILVA, J.F.C. da; CECON, P.R. Estimativas do valor energético a partir de características químicas e bromatológicas dos alimentos. Revista Brasileira de Zootecnia, v.30, p.1837-1856, 2001.

CARVALHO, M.M.; SILVA, J.L.O.; CAMPOS JUNIOR, B.A. Produção de matéria seca e composição mineral da forragem de seis gramíneas tropicais estabelecidas em um sub-bosque de angicovermelho. Revista Brasileira de Zootecnia, v.26, p.213-218, 1997.

FERREIRA, D.F. SISVAR: sistema de análise de variância. Lavras: UFLA, 1999.

FRANZLUEBBERS, A.J. Integrated crop-livestock systems in the Southeastern USA. Agronomy Journal, v.99, p.361-372, 2007.

GERALDO, J.; OLIVEIRA, L.D. de; PEREIRA, M.B.; PIMENTEL, C. Fenologia e produção de massa seca e de grãos em cultivares de milheto-pérola. Pesquisa Agropecuária Brasileira, v.37, p.1263-1268, 2002.

KATSVAIRO, T.W.; WRIGHT, D.L.; MAROIS, J.J.; HARTZOG, D.L.; RICH, J.R.; WIATRAK, P.J. Sod-livestock integration into the peanut-cotton rotation: A systems farming approach. Agronomy Journal, v.98, p.1156-1171, 2006.

KEPHART, K.D.; BUXTON, D.R. Forage quality responses of C3 and C4 perennial grasses to shade. Crop Science, v.33, p.831-837, 1993.

KOLLET, J.L.; DIOGO, J.M. da S.; LEITE, G.G. Rendimento forrageiro e composição bromatológica de variedades de milheto (Pennisetum glaucum (L.) R. BR.). Revista Brasileira de Zootecnia, v.35, p.1308-1315, 2006.

LEONEL, F. de P.; PEREIRA, J.C.; COSTA, M.G.; De MARCO JÚNIOR, P.; LARA, L.A.; QUEIROZ, A.C. de. Comportamento produtivo e características nutricionais do capim-braquiária em consórcio com milho. Revista Brasileira de Zootecnia, v.38, p.177-189, 2009.

MACEDO, M.C.M.M. Integração lavoura e pecuária: o estado da arte e inovações tecnológicas. Revista Brasileira de Zootecnia, v.38, p.133-146, 2009. Suplemento especial.

MÜLLER, M. dos S.; FANCELLI, A.L.; DOURADO-NETO, D.; GARCÍA, A.G.; OVEJERO, R.F.L. Produtividade do Panicum maximum cv. Mombaça irrigado, sob pastejo rotacionado. Scientia Agricola, v.59, p.427-433, 2002.

NORMAN, M.J.T.; PEARSON, C.J.; SEARLE, P.G.E. Pearl millet (Pennisetum glaucum). In: NORMAN, M.J.T.; PEARSON, C.J.; SEARLE, P.G.E. (Ed.). The ecology of tropical food crops. $2^{\text {nd }}$ ed. Cambridge: Cambridge University Press, 1995. p.164-181.

OLIVEIRA, E.; MEDEIROS, G.B. de; MARUN, F.; OLIVEIRA, J.C. de; SÁ, J.P.G.; COLOZZI FILHO, A.; KRANZ, W.M.; 
SILVA JÚNIOR, N.F. da; ABRAHÃO, J.J. dos S.; GUERINI, V.L.; MARTIN, G.L. Recuperação de pastagens no noroeste do paraná: bases para plantio direto e integração lavoura e pecuária. Londrina: IAPAR, 2000. 96p. (IAPAR. Informe da pesquisa, 132).

SANTOS, H.G. dos; JACOMINE, P.K.T.; ANJOS, L.H.C. dos; OLIVEIRA, V.A. de; OLIVEIRA, J.B. de; COELHO, M.R.; LUMBRERAS, J.F.; CUNHA, T.J.F. da (Ed.). Sistema brasileiro de classificação dos solos. 2.ed. Rio de Janeiro: Embrapa Solos, 2006. 306p.

SILVA, A.G. da; ROCHA, V.S.; CECON, P.R.; PORTUGAL, A.F.; PINA FILHO, O.C. Avaliação dos caracteres agronômicos de cultivares de sorgo forrageiro sob diferentes condições termo-fotoperiódicas. Revista Brasileira de Milho e Sorgo, v.4, p.28-44, 2005.
SILVA, D.J.; QUEIROZ, A.C. Análise de Alimentos: métodos químicos e biológicos. Viçosa: UFV, 2002. 235p.

SOARES, A.B.; SARTOR, L.R.; ADAMI, P.F.; VARELLA, A.C.; FONSECA, L.; MEZZALIRA, J.C. Influência da luminosidade no comportamento de onze espécies forrageiras perenes no verão. Revista Brasileira de Zootecnia, v.38, p.443-451, 2009.

TRACY, B.F.; ZHANG, Y. Soil compaction, corn yield response, and soil nutrient pool dynamics within an integrated crop-livestock system in Illinois. Crop Science, v.48, p.1211-1218, 2008.

VAN SOEST, P.J. Nutritional ecology of the ruminant. $2^{\text {nd }}$ ed. New York: Cornell University, 1994. 476p.

WILSON, J.R. Shade-stimulated growth and nitrogen uptake by pasture grasses in a subtropical environment. Australian Journal of Agricultural Research, v.47, p.1075-1093, 1996.

Recebido em 9 de maio de 2010 e aprovado em 4 de agosto de 2011 